\title{
$\beta$-catenin signaling is required for RAS-driven thyroid cancer through PI3K activation
}

\author{
Ana Sastre-Perona ${ }^{1}$, Garcilaso Riesco-Eizaguirre ${ }^{1,2}$, Miguel A. Zaballos ${ }^{1}$, Pilar \\ Santisteban ${ }^{1}$ \\ ${ }^{1}$ Instituto de Investigaciones Biomédicas "Alberto Sols", Consejo Superior de Investigaciones Científicas (CSIC) y Universidad \\ Autónoma de Madrid (UAM), Madrid, Spain \\ ${ }^{2}$ Servicio de Endocrinología, Hospital Universitario de Móstoles, Madrid, Spain
}

Correspondence to: Pilar Santisteban, email: psantisteban@iib.uam.es

Keywords: $\beta$-catenin, PI3K, RAS, thyroid cancer

Received: December 10, 2015

Accepted: June 16, 2016

Published: June 30, 2016

\section{ABSTRACT}

\begin{abstract}
Mutations in $\beta$-catenin are traditionally described as late events in thyroid cancer progression. However, the functional implications of $\beta$-catenin dysregulation in the context of tumor initiating events remain unclear. The aim of this work was to investigate whether the two main oncogenic drivers in thyroid cancer, RAS and BRAF, could activate the $W n t / \beta$-catenin pathway. Expression of HRAS ${ }^{\mathrm{v} 12}$ but not BRAF ${ }^{\mathrm{V} 600 \mathrm{E}}$ in thyroid cells induced $\beta$-catenin nuclear localization, increased $\beta$-catenin-dependent transcriptional activity and inhibited GSK3 $\beta$. In a panel of human thyroid cancer cell lines representative of the main genetic events in thyroid cancer, $\beta$-catenin activation was highly dependent on PI3K/AKT activity through its phosphorylation at S552, but not on MAPK. Silencing of $\beta$-catenin expression in cell lines led to a dramatic reduction in proliferation due to an induction of senescence, which was concordant with a reduction in tumor size in nude mice. Moreover, $\beta$-catenin silencing suppressed the expression of EMT-related genes and reduced the invasive capacity of the tumor cells. In conclusion, this work demonstrates that RAS-driven tumors induce PI3K/ AKT-dependent $\beta$-catenin activation.
\end{abstract}

\section{INTRODUCTION}

The most recent advances in thyroid cancer research emerge from an increased understanding of the mechanisms that control thyroid cell proliferation and differentiation, and the associated signal transduction pathways [1]. The current model of thyroid cancer development assumes that accumulation of mutations in tumor cells drives progression through a dedifferentiation process that leads initially to well-differentiated carcinomas, such as papillary (PTC) and follicular (FTC) thyroid carcinoma, and progresses to poorly differentiated (PDC) and undifferentiated or anaplastic (ATC) thyroid carcinomas [2, 3]. Initiation and progression of thyroid cancer comprises multiple genetic alterations, of which mutations leading to the activation of the MAPK and PI3K/AKT signaling pathways are the most studied. In PTC, MAPK activation is crucial for tumor initiation. Characterized defects in this pathway include mutations in the intracellular signal transducers RAS and BRAF, and rearrangements in the cell-membrane tyrosine kinase receptors RET (RET/PTC); these mutations are mutually exclusive [4-8]. In FTC, PI3K/AKT activation is thought to arise from RAS mutations, inactivating mutations in the PTEN or RASL1 tumor suppressor genes, or by activating mutations in PIK3CA and AKT1 [9-11]. Thyroid cancer progression to PDC and ATC involves additional mutations that stimulate other cell signaling pathways, such as p53 and Wnt/ $\beta$-catenin [12]. This latter pathway is constitutively activated in $50 \%$ of PDC and ATC due to mutations in $\beta$-catenin and Axin genes [13-15]. These mutations impair normal $\beta$-catenin degradation, resulting in its accumulation in the cytoplasm and nucleus of tumor cells, and activation of target genes involved in biological functions essential for carcinogenesis [15-19].

Although no mutations in $\beta$-catenin or Axin have been identified in PTC or FTC, $\beta$-catenin dysregulation, particularly the reduction of $\beta$-catenin plasma membrane levels as well as its aberrant nuclear localization, closely parallel loss of tumor differentiation and poor prognosis in human samples [14]. 
These data suggest that additional mechanisms, including post-translational modifications, could be responsible for $\beta$-catenin mislocalization in thyroid tumors in the absence of mutations in Wnt components. The PI3K/ AKT pathway is traditionally linked to activation of the Wnt canonical pathway through the inhibition of GSK $3 \beta$ [20], which is a critical factor of the $\beta$-catenin destruction complex. GSK3 $\beta$ phosphorylates $\beta$-catenin at S33/37/T41, resulting in its ubiquitination and degradation through the proteasome. Recent evidence has shown that Akt can directly phosphorylate $\beta$-catenin at S552, leading to its stabilization and increasing its transcriptional activity $[21,22]$. Moreover, PI3K signaling has been shown to control $\beta$-catenin activity in normal thyroid gland in response to TSH and IGFI [23]. In addition, the MAPK pathway has been described to activate Wnt signaling through ERK-mediated inhibition of GSK3 $\beta$ [24].

In an in vitro model of thyroid cancer, oncogenic RET/PTC, present only in PTC, induces $\beta$-catenin stabilization and nuclear accumulation by a Wntindependent mechanism involving activation of PI3K/ AKT and MAPK signaling pathways [25-27]. However, the consequences on $\beta$-catenin signaling in genetic contexts other than RET/PTC are unknown. Therefore, the aim of this work was to investigate whether other oncogenic drivers, such as RAS, BRAF or loss of PTEN, could activate the $\mathrm{Wnt} / \beta$-catenin pathway and participate in thyroid carcinogenesis.

Here we show that HRAS, but not BRAF, induces $\beta$-catenin activation, unveiling a novel mechanism of $\beta$-catenin stabilization in thyroid tumor cells contingent on AKT activity. These findings strongly support the functional participation of $\beta$-catenin in cell proliferation and epithelial-mesenchymal transition (EMT), and suggest that it could be a potential therapeutic target for treatment of thyroid cancer.

\section{RESULTS}

\section{RAS but not BRAF induces Wnt/ $\beta$-catenin activation in thyroid cells}

We investigated whether the Wnt/ $\beta$-catenin pathway was active in the earliest steps of thyroid tumorigenesis driven by RAS and BRAF, the two main oncogenes in thyroid cancer [28]. To do this, we used rat thyroidderived $\mathrm{PCCl} 3$ cells conditionally expressing HRAS ${ }^{\mathrm{V} 12}$ (PC-HRAS) or BRAF ${ }^{\mathrm{V} 600 \mathrm{E}}$ (PC-BRAF) after doxycycline treatment. As $\beta$-catenin stabilization is due in part to GSK $3 \beta$ inhibition, we examined GSK $3 \beta$ phosphorylation at Ser9. Doxycycline treatment for $48 \mathrm{~h}$ increased GSK3 $\beta$ levels in PC-HRAS cells but not in PC-BRAF cells, indicating that HRAS, but not BRAF, induced GSK3 $\beta$ inhibition (Figure 1A). To assess whether this inhibition modified $\beta$-catenin stabilization and its nuclear localization, we analyzed $\beta$-catenin expression in total, cytoplasmic and nuclear extracts from PC-HRAS and PC-BRAF cells treated or not with doxycycline. Whereas both HRAS and BRAF oncogenes induced a minor increase in total $\beta$-catenin levels (Figure 1B), only HRAS expression increased nuclear $\beta$-catenin expression (Figure 1C). These findings were confirmed by immunocytochemistry and confocal imaging (Figure 1D). To test whether $\beta$-catenin nuclear expression increased its transcriptional activity, PC-HRAS and PC-BRAF cells were transfected with the artificial Top/Fop promoter, which contains several $\beta$-catenin/TCF binding sites in tandem, and luciferase activity was measured. Cells were treated with $\mathrm{LiCl}$ as a positive control of $\beta$-catenin transcriptional activation. Expression of HRAS resulted in a robust and time-dependent increase in luciferase activity, reaching more than 10 -fold at $48 \mathrm{~h}$. By contrast, BRAF expression resulted in a minor increase (2-fold) in luciferase activity at $48 \mathrm{~h}$ after transfection (Figure 1E). To confirm that the reduced ability of BRAF to activate Top/Fop was not because of an overall reduced output of BRAF with respect to HRAS cells, we measured the ability of both oncogenes to activate the ERK effector ELK1. Expression of BRAF and HRAS induced the activation of ELK1 to a similar level (Figure 1F). These results show that HRAS, unlike BRAF, induces strong $\beta$-catenin stabilization and activation in thyroid cells.

\section{PI3K stimulates $\beta$-catenin expression and activity in human thyroid tumor cells, which is dependent on its phosphorylation at Ser 552}

To assess the status of $\mathrm{Wnt} / \beta$-catenin signaling in human thyroid cancer, we surveyed $\beta$-catenin subcellular localization and transcriptional activity in a panel of human thyroid cell lines representative of the main histologic types, and harboring the main genetic mutations of thyroid cancer (Figure 2). Human HT29 colon carcinoma cells carrying the APC mutation [29] and Nthyori 3-1 immortalized normal epithelial human thyroid cells [30] served as positive and negative controls, respectively. To assess the subcellular localization of $\beta$-catenin, we performed immunocytochemistry and confocal imaging (see Supplementary Figure 1 and summary in Figure 2A). According to the subcellular localization of $\beta$-catenin, we found three types of cells. One type expressed $\beta$-catenin exclusively in the plasma membrane (8505c, T238, Cal62 and Nthy-ori 3-1). A second type expressed $\beta$-catenin both in the plasma membrane and in the cytoplasm, with a marked perinuclear accumulation (WRO and FRO). A third type of cell expressed $\beta$-catenin exclusively in the nucleus (FTC133, SW1736, Hth7, Hth83, C643, TPC1 and KTC1), comparable with HT-29 colon carcinoma. Of note, the majority of RAS mutated cells (3 out of 4) presented $\beta$-catenin nuclear localization.

We next assessed $\beta$-catenin transcriptional activity (Figure 2B). Unexpectedly, no correlation was found 
between the subcellular distribution of $\beta$-catenin and its transcriptional activity (Figure 2A, 2B). Generally, $\beta$-catenin transcriptional activity in thyroid cancer cell lines was lower ( 2 -fold) than in HT-29 positive cells (5-fold). Notably, FCT133 cells, which harbor a PTEN deletion, had the greatest $\beta$-catenin transcriptional activity, up to $>3$-fold.

Since FTC133 exhibited robust nuclear $\beta$-catenin expression and had the highest transcriptional activity, we

A

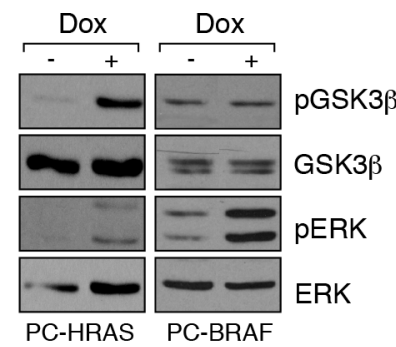

B
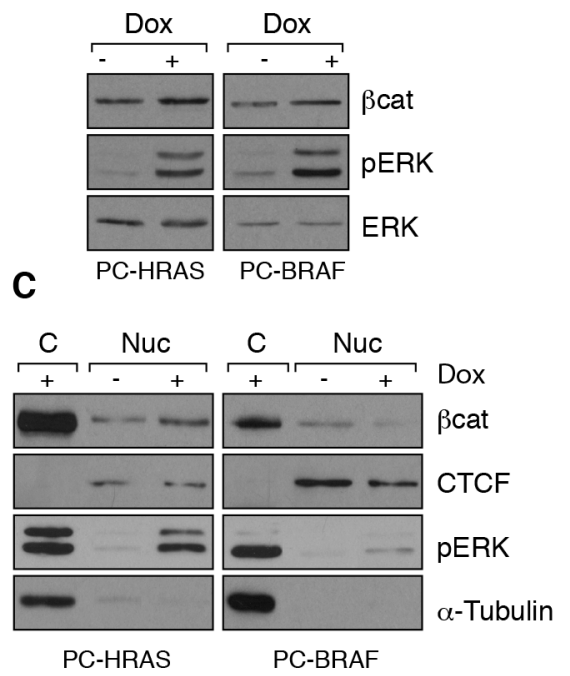

$\mathbf{E}$

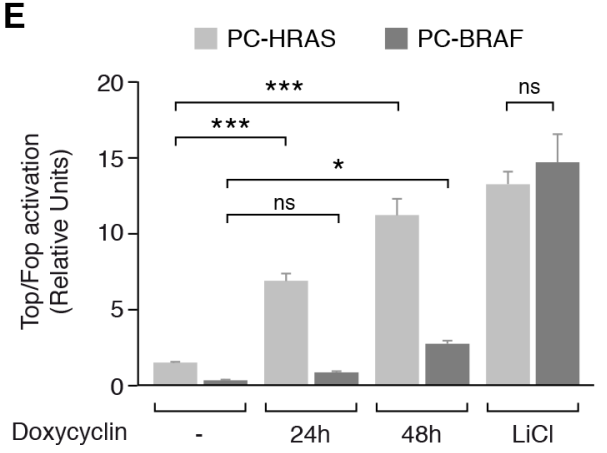

used this cell line to examine the mechanisms of activation of $\beta$-catenin signaling. FTC133 cells derive from a follicular thyroid carcinoma, harbor a PTEN deletion and, accordingly, exhibit a high PI3K activity as shown by their high levels of AKT phosphorylation (Figure 3A). Western blotting of total cell extracts revealed high expression of total $\beta$-catenin in FTC133 cells (Figure 3A), which was comparable to its expression in HT-29 and TPC-1 cells,

D

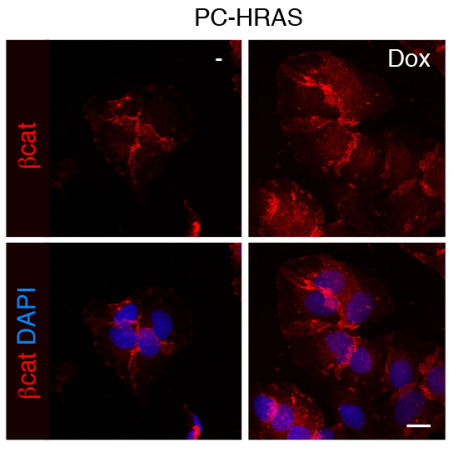

PC-BRAF

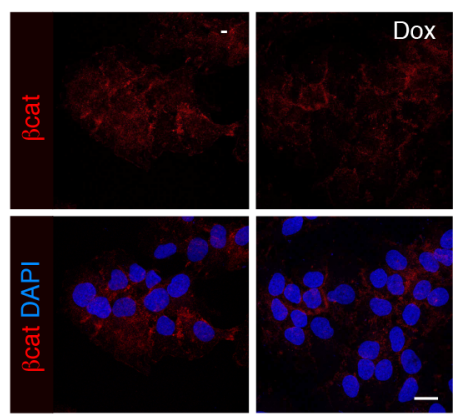

F

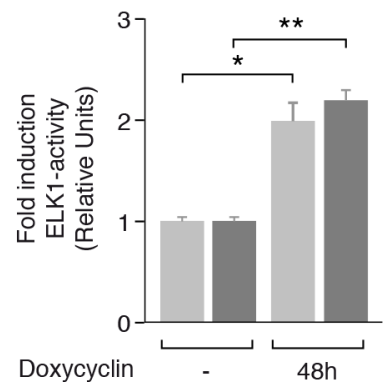

Figure 1: Wnt/ $\beta$-catenin activation in PCCl3 cells conditionally expressing HRAS ${ }^{\mathrm{V} 12}$ (PC-HRAS) or BRAF ${ }^{\mathrm{V} 600 \mathrm{E}}$ (PC-BRAF). PC-HRAS and PC-BRAF cells were starved for $48 \mathrm{~h}$ and then treated with doxycycline for the times indicated. (A and B). Total proteins extracts were analyzed by western blot for the detection of p-GSK3 $\beta$ (panel A) and $\beta$-catenin ( $\beta$ cat) (panel B). (C) Nuclear (Nuc) and cytoplasmic (C) protein extracts were analyzed by western blot for the detection of $\beta$-catenin. CTCF and $\beta$-tubulin were used as nuclear and cytoplasmic loading controls, respectively. (D) Cells were grown on cover-slips, fixed and stained with a $\beta$-catenin antibody (red). Nuclei were stained with DAPI (blue). Scale bar $10 \mu \mathrm{m}$. (E) $\beta$-catenin transcriptional activity was measured in cells transfected with Super8x TopFlash (Top) or Super8x FopFlash (Fop) vectors after 24 and $48 \mathrm{~h}$ of doxycycline treatment or $48 \mathrm{~h}$ of $\mathrm{LiCl}$ treatment. Data show fold induction of the Top/Fop ratio with respect to non-treated cells (-). (F) ELK-1 activation was measured in cells transfected with the reporter vector pGE51-luc, encoding the transactivation domain of Elk-1 (amino acids 307 to 428) fused to the GAL4 DNA-binding domain, and a pRL-CMV Renilla construct, after $48 \mathrm{~h}$ in the presence (+) or absence (-) of doxycycline. Data show fold induction of ELK-1 activation relative to Renilla levels. Values represent means $\pm \operatorname{SEM}(n=3) .{ }^{*} p<0.05 ; * * p 0.01 ; * * * p<0.001$. 
two cell types exhibiting $\beta$-catenin activation $[25,31]$. Interestingly, FTC133 also showed high levels of $\beta$-catenin phosphorylated at Ser552, which promotes $\beta$-catenin entry into the nucleus and increases its transcriptional activity (Figure 3A) [21, 32]. We previously reported that TSH and IGF1, through PKA and AKT, respectively, phosphorylate $\beta$-catenin at Ser552 in normal differentiated $\mathrm{PCCl} 3$ thyroid cells [23]. In thyroid tumor cells, the cAMP/PKA pathway is impaired due to oncogene activation $[33,34]$. To determine whether $\beta$-catenin phosphorylation was a direct consequence of PI3K/AKT activation, FTC133 cells were treated with Akti1/2, a specific AKT inhibitor, and phospho-Ser552 $\beta$-catenin levels were measured. AKT inhibition decreased phospho-Ser552 $\beta$-catenin expression (Figure $3 \mathrm{~B}$ ) and subsequent $\beta$-catenin transcriptional activity (Figure 3C). By contrast, MAPK/MEK inhibition failed to suppress $\beta$-catenin transcriptional activity in FTC133 cells (Figure 3C). In HT-29 cells, which do not have a constitutively active PI3K pathway (Figure 3A), the transcriptional activity of $\beta$-catenin was unaffected by AKT inhibition (Figure 3C). Consistent with these results, confocal imaging showed that phospho-Ser552 $\beta$-catenin was localized in the nuclei of FTC133 cells and its presence was contingent on AKT activity (Figure 3D).

In light of these findings and since $\mathrm{BRAF}^{\mathrm{V} 600 \mathrm{E}}$ oncogene activates MAPK pathway and HRAS ${ }^{\mathrm{V} 12}$ oncogene activates both MAPK and PI3K pathways, we evaluated phospho-Ser552 $\beta$-catenin levels in PC-BRAF and PC-HRAS cells. HRAS but not BRAF activation increased phospho-Ser552 $\beta$-catenin levels in $\mathrm{PCCl} 3$ cells (Figure 3E). In agreement with this finding, whereas RAS mutant human cell lines (Hth7 and C643) expressed phospho-Ser552 $\beta$-catenin that was dependent on AKT activity (Figure 3F), the BRAF mutant cell line BCPAP did not. These data strengthen the notion that PI3K/AKT stabilizes $\beta$-catenin in thyroid cancer.

PI3K/AKT-mediated phosphorylation of $\beta$-catenin at Ser552, unlike phosphorylation at the N-terminus, increases its stabilization, leading to its accumulation and translocation into the nucleus [22]. To test if this mechanism was indeed responsible for $\beta$-catenin stability in FTC133 cells, we used bortezomib to inhibit proteasome activity and co-treated cells with/without Akti1/2 to inhibit AKT activity. Western blotting showed that the degradation of total $\beta$-catenin after AKT inhibition was impaired with bortezomib and, thus, dependent on proteasome activity (Figure 3G). This result shows that phosphorylation at Ser552 is essential for AKT-induced $\beta$-catenin stabilization.

Finally, to examine whether the canonical Wnt pathway participated in PI3K/AKT-mediated stabilization of $\beta$-catenin, we inhibited Wnt signaling in FTC133 cells with XAV939 [35]. Inhibition had no effect on phosphoSer552 $\beta$-catenin levels, suggesting that PI3K/AKTmediated stabilization of $\beta$-catenin is independent of Wnt. However, inhibition of Wnt signaling decreased total $\beta$-catenin expression and increased phospho-Ser33/37/T41$\beta$-catenin, an $\mathrm{N}$-terminal phosphorylation that promotes $\beta$-catenin degradation (Figure 3G) [35]. By contrast, inhibition of AKT had no effect on phosphorylation at
A

\begin{tabular}{|c|c|c|c|}
\hline $\begin{array}{c}\text { Type of } \\
\text { Carcinoma }\end{array}$ & $\begin{array}{l}\text { Cell } \\
\text { line }\end{array}$ & $\begin{array}{l}\text { Mutation } \\
\text { Described }\end{array}$ & $\begin{array}{c}\beta \text { catenin } \\
\text { Localization }\end{array}$ \\
\hline Colon & HT29 & APC & Nuclear \\
\hline Control & NthyORI & - & Membrane \\
\hline \multirow{3}{*}{ PTC } & TPC-1 & RET/PTC & Nuclear \\
\hline & KTC1 & BRAFV600E & Nuclear \\
\hline & BCPAP & BRAFV600E & Membrane \\
\hline \multirow{2}{*}{ FTC } & FTC133 & $\mathrm{PTEN} \Delta / \mathrm{R} 130$ & Nuclear \\
\hline & WRO & - & Perinuclear/Membrane \\
\hline \multirow{8}{*}{ ATC } & FRO & BRAFV600E & Perinuclear/Membrane \\
\hline & $8505 c$ & BRAFV600E & Membrane \\
\hline & SW1736 & BRAFV600E & Nuclear \\
\hline & T238 & - & Membrane \\
\hline & Cal62 & KRASG12R +/- & Membrane \\
\hline & Hth7 & NRAS & Nuclear \\
\hline & Hth83 & HRAS & Nuclear \\
\hline & $\mathrm{C} 643$ & HRAS & Nuclear \\
\hline
\end{tabular}

B $\quad$ catenin transcriptional activity Top/Fop (Relative Units)

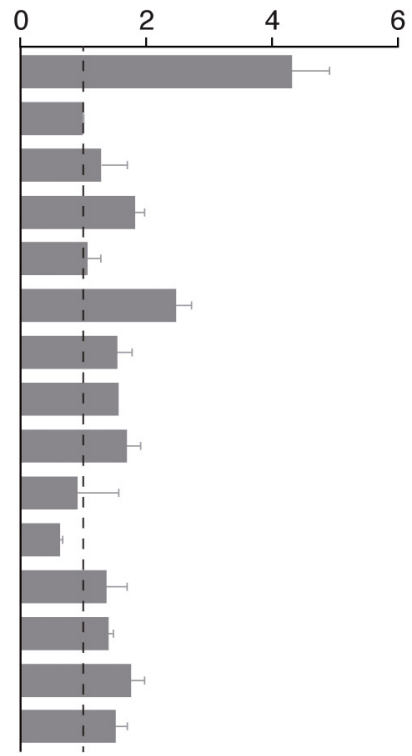

Figure 2: $\beta$-catenin subcellular localization and transcriptional activity in a panel of human thyroid cancer cell lines. (A) Table summarizing classification, mutations described and $\beta$-catenin localization in different thyroid cell lines. $\beta$-catenin localization was analyzed by immunocytochemistry and confocal imaging as shown in Supplementary Figure 1. (B) $\beta$-catenin transcriptional activity was measured in Super8x (Top) or Super8x FopFlash vector-transfected cells. Data show fold induction of the Top/Fop ratio with respect to non-treated cells $(-)$. Values represent means $\pm \operatorname{SEM}(n=3)$. 
A

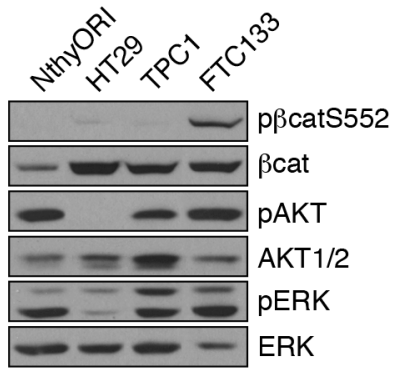

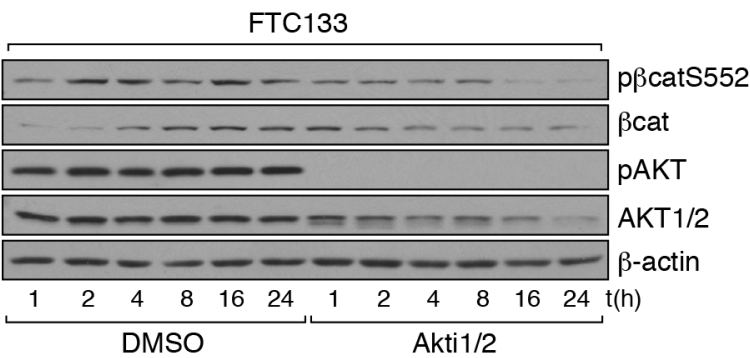

C

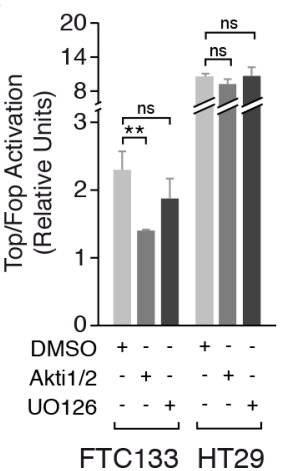

D
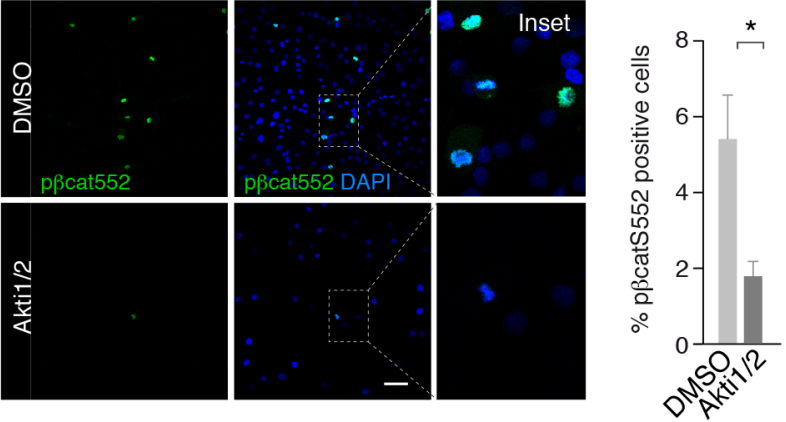

E

PC-HRAS PC-BRAF

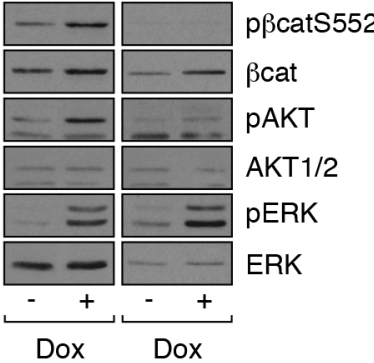

F

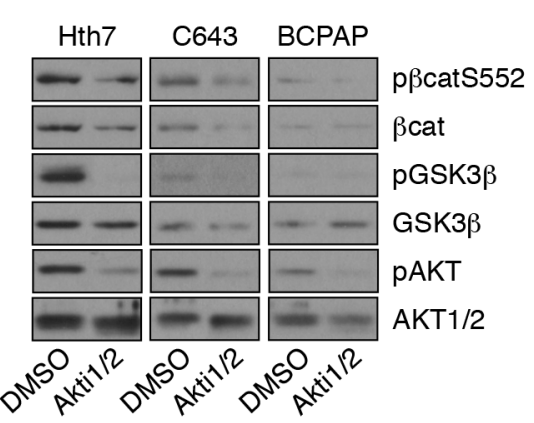

G

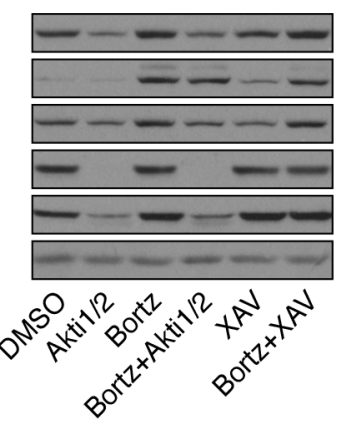

pßcatS552

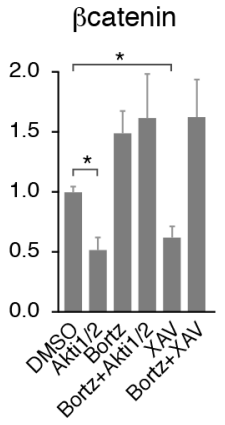

Figure 3: PI3K/AKT signaling controls $\beta$-catenin expression through its phosphorylation at serine 552. (A, B) $\beta$-catenin and $\mathrm{p} \beta$-cateninS552 expression levels were analyzed by western blot in the indicated cell lines and in FTC133 cells treated with DMSO or with Aktil/2 for the specified times. (C) $\beta$-catenin transcriptional activity was analyzed in FTC133 and HT29 cells after treatment with DMSO, Akti1/2 or UO126 for $24 \mathrm{~h}$. Data show fold induction of the Top/Fop ratio with respect to non-treated cells $(-)$. Values represent means $\pm \operatorname{SEM}(n=3) .{ }^{*} p<0.05 ; * *<<0.01 ; * * * p<0.001$. (D) FTC133 cells were grown on cover-slips, treated with DMSO or Akti1/2 for $24 \mathrm{~h}$, fixed and stained for $\mathrm{p} \beta$-cateninS552 (green). Nuclei were stained with DAPI (blue). Scale bar $25 \mu \mathrm{m}$. The insets show higher magnifications of the regions marked by a square. (E) PC-HRAS and PC-BRAF were starved for $48 \mathrm{~h}$ and then treated with doxycycline for $48 \mathrm{~h}$. Total protein extracts were analyzed by western blot for $\mathrm{p} \beta$-cateninS552. (F) The indicated cell lines were treated with DMSO or Akti1/2 and total protein extracts were analyzed by western blot for the detection of $\beta$-catenin and p $\beta$-cateninS552. (G) Left panel: FTC133 cells were pre-treated for $1 \mathrm{~h}$ with bortezomib (Bortz) and then treated with DMSO, Akti1/2 or XAV939 (XAV) for $8 \mathrm{~h}$. Total protein extracts were analyzed by western blot for the detection of $\mathrm{p} \beta$-cateninS552 and $\mathrm{p} \beta$-cateninS33/37/T41. Right panel: quantification of protein levels normalized to $\beta$-actin. Values represent means $\pm \operatorname{SEM}(n=3) .{ }^{*} p<0.05$; ${ }^{*} p<0.01$; ns not significant. 
the N-terminus. Collectively, these results suggest that $\mathrm{PI} 3 \mathrm{~K} / \mathrm{AKT}$ and Wnt induce $\beta$-catenin stabilization through independent mechanisms in thyroid cancer cells that is dependent on its phosphorylation status, similar to that described in normal thyroid cells [23].

Overall, these data support a critical function for PI3K/AKT signaling, but not MAPK signaling, in $\beta$-catenin stabilization in thyroid tumor cells. This PI3K/ AKT-controlled stabilization of $\beta$-catenin occurs through its phosphorylation at Ser552 and is independent of Wnt.

\section{$\beta$-catenin silencing inhibits proliferation and induces senescence in human thyroid tumor cells}

To study the role of $\beta$-catenin in thyroid tumor cell proliferation, we used a lentivirus expressing a short hairpin RNA (shRNA) to stably silence $\beta$-catenin in FTC133 cells (Figure 4A). As expected, the level of DNA synthesis in $\beta$-catenin shRNA cells was decreased by $50 \%$ relative to scrambled shRNA-transfected cells (Figure 4B). This was paralleled by a decrease in proliferation of $\beta$-catenin shRNA cells (Figure 4C). Similarly, a significant decrease in DNA synthesis was detected in $\beta$-catenin shRNA-transfected RAS mutant thyroid cancer cell lines (C643, Hth83, and Hth7) (Figure 4D). To confirm that this effect was due to $\beta$-catenin transcriptional activity and not because of its role in cell adhesion, we stably expressed a dominant-negative form of FLAG-tagged TCF4 (Transcription factor 7-like 2 gene) in FTC133 cells, which does not bind $\beta$-catenin [36], and measured DNA synthesis. BrdU incorporation was significantly lower in TCF4-expressing cells than in controls (Figure 4B), suggesting that FTC133 cell proliferation required the transcriptional activity of $\beta$-catenin independent of its involvement in cell adhesion.

Since cyclinD1 is a direct downstream target of $\beta$-catenin activation, we sought to study its function in cell proliferation. Unexpectedly, silencing of $\beta$-catenin markedly increased cyclin D1 levels (Figure 5A) and also the levels of the cell cycle inhibitors p27 $7^{\text {kip } 1}$ and p21 (Figure 5A, 5B). This surprising result led us to hypothesize that the high expression of cyclin D1 and cell cycle inhibitors were in fact indicators of senescence. Indeed, previous studies have demonstrated that upregulation of cyclinD1 occurs in senescent cells [37-39]. Thus, we determined $\beta$-galactosidase (SA- $\beta$-gal)

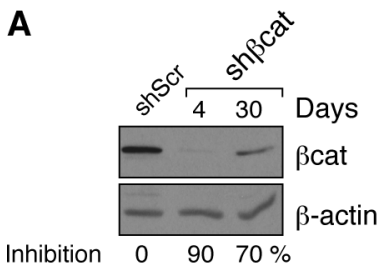

C

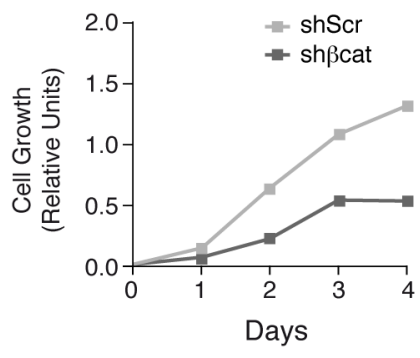

B

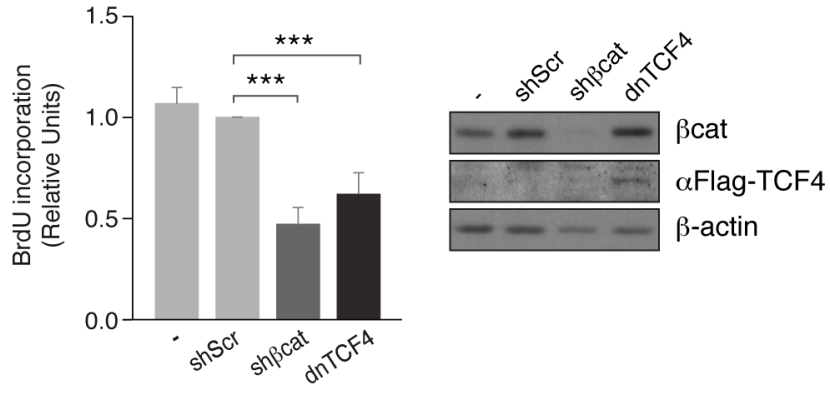

D

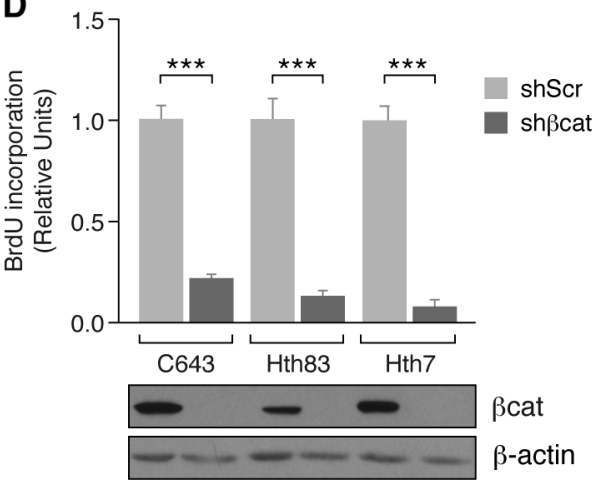

Figure 4: $\boldsymbol{\beta}$-catenin inhibition decreases proliferation in human tumoral thyroid cells. (A) FTC133 cells were infected with control (shScr) or $\beta$-catenin (sh $\beta$ cat) lentivirus shRNAs. Total protein extracts were obtained at the indicated times and analyzed by western blot for $\beta$-catenin expression. (B) Left panel: FTC133 cells were infected with control (shScr) or $\beta$-catenin ( $\operatorname{sh} \beta$ cat) lentivirus shRNAs or a dominant-negative form of TCF4 [dnTCF4] and BrdU incorporation was calculated. Data show BrdU incorporation relative to that of cells infected with the vehicle vector ( $\operatorname{shScr}$ ). Values represent means $\pm \operatorname{SEM}(n=3)$. ${ }^{* * *} p<0.001$. Right panel: western blot analyis of TCF4 expression (C) FTC133 cells were infected with control (shScr) or $\beta$-catenin (sh $\beta$ cat) lentivirus shRNAs and cell growth was estimated relative to the density at day 0 . Values represent means $\pm \operatorname{SEM}(n=3)$. (D) Cell lines were infected with control $(\operatorname{shScr})$ or $\beta$-catenin $(\operatorname{sh} \beta c a t)$ lentivirus shRNAs and BrdU incorporation was calculated. Data show BrdU incorporation relative to that of the cells infected with the vehicle vector (shScr). ${ }^{* * *} p<0.001$. 
activity as a metric of senescence. Silencing of $\beta$-catenin resulted in a significant increase in the percentage of SA- $\beta$ gal-positive cells relative to non-silenced controls (Figure $5 \mathrm{C})$. Comparable results were obtained in $\beta$-cateninsilenced C643 and Hth7 cells (Figure 5D), demonstrating that $\beta$-catenin silencing also increases senescence in RAS mutant human thyroid cell lines.

To verify this finding in vivo, we injected control or $\beta$-catenin shRNA FTC133 cells subcutaneously into immunocompromised NOD-SCID mice and monitored the development of xenografts. Xenograft tumor size was dramatically reduced in $\beta$-catenin-silenced tumors with respect to the control tumors (Figure 5E). Importantly, the expression levels of $\beta$-catenin remained inhibited in xenografts of $\beta$-catenin-silenced cells compared with the control cells (Figure 5F). Collectively, these results strongly suggest that inhibition of $\beta$-catenin activity decreases thyroid tumor cell proliferation by promoting cell cycle arrest and inducing senescence.

\section{B-catenin silencing induces E-cadherin expression and diminishes EMT markers expression and tumor cell invasion}

A feature common to epithelial tumor cells is the acquisition of a mesenchymal phenotype characterized by an increased invasion capacity. Epithelial-mesenchymal transition (EMT) is induced by many signaling pathways including $\mathrm{Wnt} / \beta$-catenin and is characterized by the loss of E-cadherin expression through activation of transcriptional repressors such as $\beta$-catenin/TCF, Snail, Slug, TWIST or ZEB1/2 [40]. Inhibition of E-cadherin expression has been described in BRAF-driven thyroid tumors in which the MAPK pathway is activated [41], but little is known about the mechanisms involved in E-cadherin repression in RAS-driven tumors where PI3K/ AKT is activated. Given our findings of PI3K regulation of $\beta$-catenin activity, we examined its role on E-cadherin expression in FTC133 thyroid cells. Silencing of $\beta$-catenin resulted in an increase in E-cadherin protein and mRNA expression (Figure 6A, 6B). This was accompanied by a decrease in the expression of transcription factors Slug and Twist, which are also controlled by $\beta$-catenin/TCF [42]. Similarly, the expression of EMT target genes N-cadherin and ZEB1 [43] were also reduced in $\beta$-catenin-silenced cells (Figure 6B). Interestingly, although not a target gene of the $\beta$-catenin/TCF complex, silencing of $\beta$-catenin in FTC133 markedly decreased Snail expression, whereas the expression of other mesenchymal genes such as fibronectin or vimentin was unchanged (Figure 6B). As EMT is ultimately responsible for tumor cell migration and invasion, we examined the invasion capacity of $\beta$-catenin-silenced FTC133 cells using Matrigel assays. As anticipated, these cells exhibited a significant 3-fold reduction in their invasiveness with respect to the control scramble cells (Figure 6C).

\section{DISCUSSION}

We show that RAS but not BRAF signals through $\beta$-catenin and controls essential oncogenic functions in thyroid cancer cells. HRAS acts predominantly through PI3K/AKT to stabilize $\beta$-catenin via two mechanisms, GSK3 $\beta$ inhibition and direct $\beta$-catenin phosphorylation at Ser552. PI3K/AKT-mediated $\beta$-catenin activation protects cells from senescence and increases cell proliferation, EMT and cell invasion.

Mutations in $\beta$-catenin have been identified in the most aggressive forms of thyroid cancer, such as poorly differentiated and anaplastic carcinomas. In addition, aberrant expression of $\beta$-catenin and its abnormal cellular localization in the cytoplasm and nucleus occur in tumor cells of differentiated thyroid cancer [14] and, in accordance with our findings, correlates with the presence of oncogenic RAS [14]. The consequences of this dysregulation as well as the functional implications of $\beta$-catenin activating mutations are of great interest due to the potential impact on pathogenesis. Studies on melanoma, a cancer in which $\beta$-catenin is also activated, suggest that the results of Wnt/ $\beta$-catenin signaling activation are complex and likely context-dependent [44]. Similarly, we show here that in the context of precisely defined genetic changes, such as RAS and PTEN loss, $\beta$-catenin is stabilized and expressed in the nucleus and mediates pro-oncogenic effects including evasion from oncogene-induced senescence, EMT and invasion.

An improved understanding of thyroid cancer genetics is beginning to pave the way for the molecular classification of these tumors based on fundamental driving mutations. PTC is a MAPK-driven cancer that has two mutually exclusive drivers with distinct signaling outcomes: BRAF ${ }^{\mathrm{V} 600 \mathrm{E}}$ and mutated RAS. Tumors driven by $\mathrm{BRAF}^{\mathrm{V} 600 \mathrm{E}}$ have high MAPK-signaling and tumors driven by RAS and receptor tyrosine kinase fusions (e.g. RET/PTC) have low MAPK-signaling and have concurrent activation of PI3K/AKT [28] [45]. FTC is considered predominantly driven by $\mathrm{PI} 3 \mathrm{~K} / \mathrm{AKT}$ activation through mutations in RAS, PTEN and RASL1 loss, or by activating mutations in PIK3CA and AKT1 $[10,46]$. Overlapping mutations in components of both pathways have been found in the full metastatic thyroid cancer phenotype $[47,48]$. The interaction of $\beta$-catenin with these oncogenic driver mutations is of great interest as it may determine the fate of the tumor. In transgenic melanoma models, concurrent BRAF ${ }^{\mathrm{V} 600 \mathrm{E}}$ and PTEN loss requires $\beta$-catenin stabilization to promote metastasis to lymph nodes and lungs [44]. By contrast, in the presence of wild-type PTEN, BRAF ${ }^{\mathrm{V} 600 \mathrm{E}}$ tumors do not metastasize independently of $\beta$-catenin status. Here we show that mutated RAS-driven thyroid tumors need $\beta$-catenin stabilization for tumor progression and this effect requires PI3K/AKT activation and is independent of MAPK signaling. 
It has previously been demonstrated that oncogenic RET/PTC rearrangements stabilize $\beta$-catenin, promoting its accumulation in the nucleus and enhancing its activity [25]. Similar to RAS, RET/PTC also results in lower MAPK-signaling and activation of PI3K/AKT [25, 28]. In the presence of RET/PTC rearrangements, the group of Santoro observed that $\beta$-catenin stabilization induces a mitogenic effect through the upregulation of TCF/LEFinduced cyclin D1 [49]. By contrast, in the presence of RAS or PTEN loss, we found a strong upregulation of cyclin D1 following $\beta$-catenin silencing. Cyclin D1 upregulation is an established marker of senescence and, accordingly, we found that $\beta$-catenin silencing induced senescence. The reasons for this discrepancy between RET/PTC and RAS/PTEN loss remain incompletely understood. A possible explanation is that in our experiments we achieved a much greater $\beta$-catenin silencing than obtained by Castellone et al. [25] and this may be necessary to induce senescence. Additionally, these differences also emphasize that defining the biological effects of $\beta$-catenin signaling in thyroid cancer may not be possible out of the context of other mutational changes and should help to better classify thyroid cancer into biologically meaningful groups.

Although human thyroid cancer cells with RAS mutations or PTEN loss show strong $\beta$-catenin nuclear localization, there is only a modest activation of the $\beta$-cat/ TCF reporter relative to cells without $\beta$-catenin in the nucleus (Figure 2). $\beta$-catenin is a transcriptional regulator that cannot bind DNA by itself and requires binding to
A
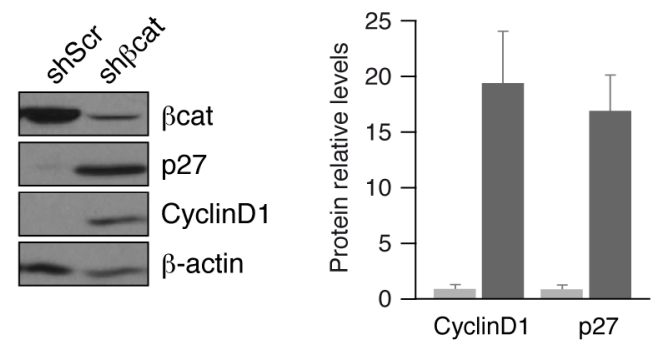

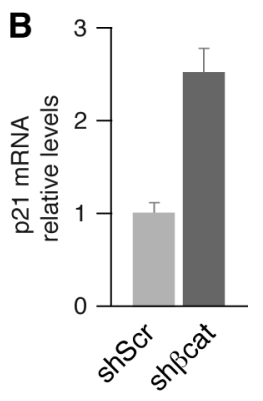

D

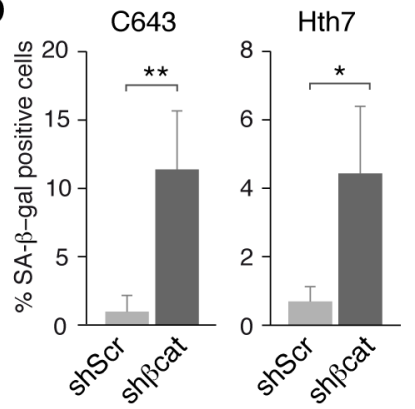

E
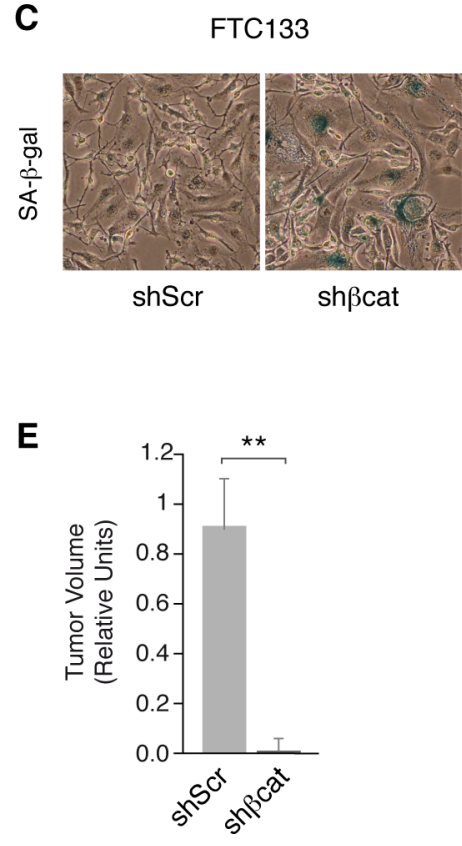

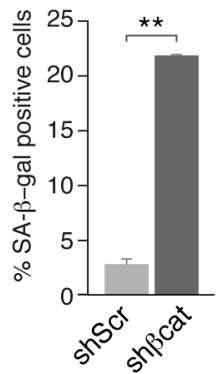

$\mathbf{F}$

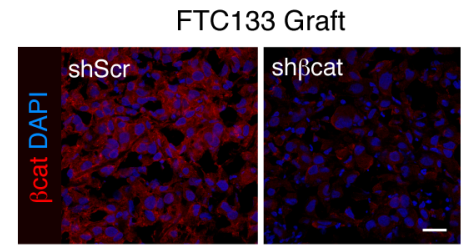

Figure 5: $\beta$-catenin inhibition induces cell senescence and reduces tumor growth in human tumoral thyroid cells. (A) FTC133 cells were infected with control $(\mathrm{shScr})$ or $\beta$-catenin $(\operatorname{sh} \beta$ cat) lentivirus shRNAs. Left panel: total protein extracts were obtained and analyzed by western blot for the detection of $\beta$-catenin, cyclinD1 and p27. Right panel: quantification of cyclinD1 and p27 protein levels normalized to $\beta$-actin. Values represent means $\pm \operatorname{SEM}(n=3)$. (B) p21 mRNA expression levels were analyzed in FTC133 shScr and sh $\beta$ cat-infected cells. (C) FTC133 cells were infected with control (shScr) or $\beta$-catenin ( $\operatorname{sh} \beta$ cat) lentivirus shRNAs and analyzed for SA- $\beta$ gal-positivity. Left panel: representative $\beta$ gal-staining. Right panel: percentage of SA- $\beta$ gal positive cells per field. Values represent means $\pm \operatorname{SEM}(n=3) .{ }^{*} p<0.01$. (D) C643 and Hth83 cells were infected with control (shScr) or $\beta$-catenin (sh $\beta$ cat) lentivirus shRNAs and analyzed for SA- $\beta$ gal-positivity. Percentage of SA- $\beta$ gal positive cells per field. Values represent means $\pm \operatorname{SEM}(n=3)$. $* * p<0.01$. (E) FTC133 control (shScr) or sh $\beta$ cat cells were injected in NOD-SCID mice and the tumor volume was measured at the end of the experiment. Values represent means $\pm \operatorname{SEM}(n=3) . * * p<0.01$. (F) FTC133 grafts from control (shScr) or sh $\beta$ cat cells were stained with a $\beta$-catenin antibody (red). Nuclei were stained with DAPI (blue). Scale bar $25 \mu \mathrm{m}$. 
other transcription factors to increase the expression of its target genes. Even though TCF/LEF transcription factors are the most studied $\beta$-catenin partners, growing evidence suggest that $\beta$-catenin can associate with other DNA-binding transcription factors, such as FoxO1 [50], the nuclear receptor LRH1 [51] or the thyroid transcription factor Pax8 [23]. Differential expression of those factors in thyroid cells lines could explain the variable $\beta$-catenin transcriptional activity found herein. Future studies will be necessary to identify $\beta$-catenin target genes in the thyroidspecific context.

Another interesting observation is that Cal62 cells, which harbor a K-RAS mutation, present $\beta$-catenin in the membrane, while cells harboring H or N-RAS mutations show nuclear $\beta$-catenin localization. RAS isoforms are functionally non-redundant, mainly due to their different subcellular localization, and it has been shown that K-RAS signals preferentially via BRAF/MAPK while the other isoforms have PI3K as their main effector [52].

How $\beta$-catenin is activated may have important functional implications for its potential use as a therapeutic target. In addition to GSK3 $\beta$ inhibition, Castellone's work demonstrated RET-induced phosphorylation in $\beta$-catenin at Tyr654 residue. This phosphorylation event is dependent on tyrosine kinase receptors, such as ERB and SRC $[53,54]$, but has no relationship with AKT activation. By contrast, in a RAS-like genetic context where PI3K/
AKT activation is present, phosphorylation of $\beta$-catenin at Ser552 seems to be predominant and is very sensitive to AKT inhibition. Ser552 phosphorylation has been shown to be independent of Wnt factors and MAPK signaling. Thus, strategies to inhibit these signaling pathways may have a very limited effect on $\beta$-catenin activation in RAS-like tumors, whereas AKT inhibition and/or direct inhibition of $\beta$-catenin Ser552 phosphorylation could be a more specific mechanism to inhibit its pro-metastatic effects.

Components of the MAPK and PI3K/AKT signaling pathways are important molecular targets for new cancer therapeutics. For example, selumetinib (a MEK inhibitor) and vemurafenib and dabrafenib (mutant BRAF inhibitors) are clinically beneficial in thyroid cancer patients with advanced metastatic disease. However, resistance to kinase inhibitors targeting components of these signaling pathways is a common phenomenon in patients with advanced radioactive iodine-refractory differentiated thyroid cancer [55]. Understanding how simultaneous activation of additional signaling pathways in a given tumor can impact inhibitor-targeted pathways is essential and may assist in explaining why some patients with a given driver mutation respond differentially to treatment with the same inhibitor. In this context, it is particularly noteworthy that changes in $\beta$-catenin can have such significant effects in RAS-driven tumors.
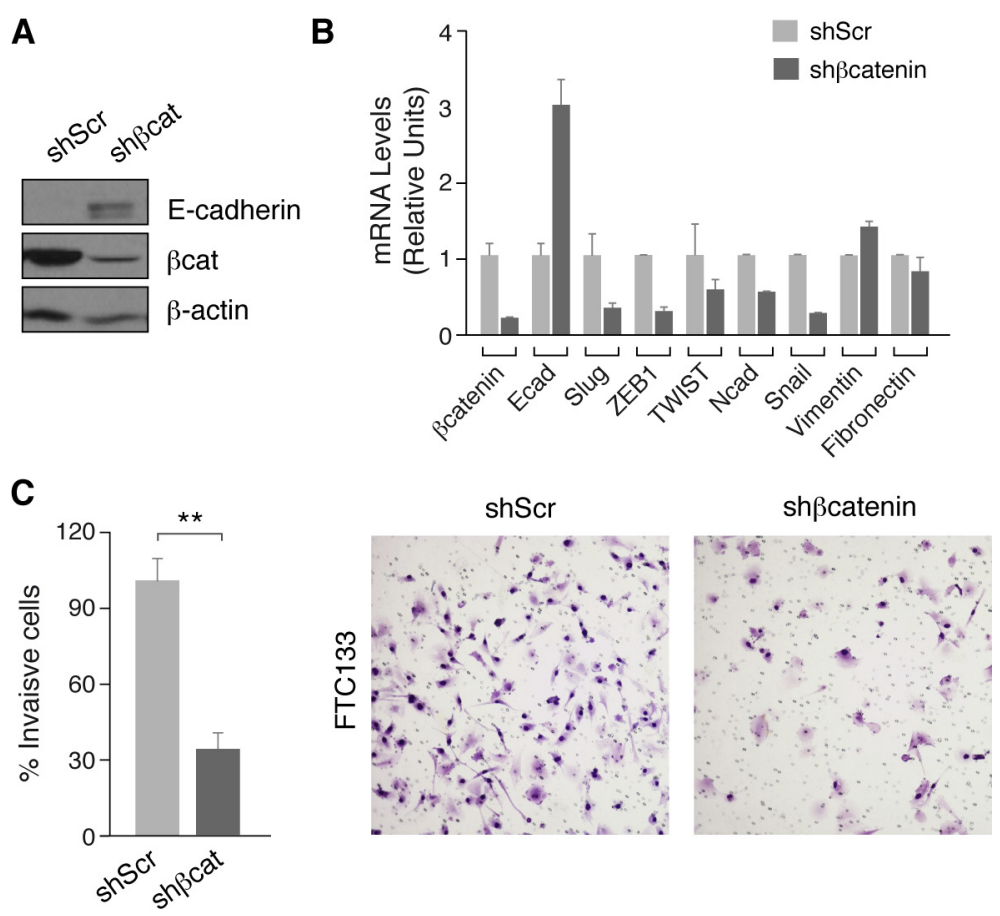

Figure 6: $\beta$-catenin silencing decreases expression of EMT markers and inhibits cell migration of human thyroid tumoral cells. (A) FTC133 cells were infected with control (shScr) or $\beta$-catenin (sh $\beta$ cat) lentivirus shRNAs. Total protein extracts were analyzed by western blot for the detection of $\beta$-catenin and E-cadherin. (B) Expression of selected EMT genes. Data show the relative expression levels compared with the control cells. (C) The invasive capacity of FTC133 control or sh $\beta$-catenin cells was analyzed in Matrigel-coated Transwells. Left panel: number of cells invading the lower chamber after $24 \mathrm{~h}$. A total of 10 fields for each cell line were quantified. Values represent means $\pm \operatorname{SEM}(n=3){ }^{* *} p<0.01$. Right panel: representative images of Transwell filters. 
In conclusion, we provide new insights into the mechanisms by which alterations in $\beta$-catenin signaling impact thyroid cancer formation and progression. Depending on the genetic context (RAS-driven tumors and those where PI3K/AKT is predominantly activated such as PTEN-deficient tumors), $\beta$-catenin is stabilized specifically through phosphorylation at Ser552 and this event protects cells from oncogene-induced senescence and contributes to EMT and cell invasion. $\beta$-catenin targeting approaches could therefore have potential utility in thyroid cancer, particularly in combination with other therapies. Given the interconnectedness of $\beta$-catenin signaling with other oncogenes and tumor suppressor pathways, further studies are clearly necessary to explore the potential value of combinatorial therapies. We believe that our study, together with those reported by Castellone et al. [17] and Gujral et al. [56], will help to identify the genetic factors and biomarkers that can predict responses to treatment with $\beta$-catenin pathway modulators, either alone or in combination with other therapies, and will be an important next step in determining the utility of these potential new therapies.

\section{MATERIALS AND METHODS}

\section{Cell culture}

HeLa and HEK293T cell lines were grown in Dulbecco's modified Eagle's medium (DMEM) supplemented with $5 \%$ and $10 \%$ fetal bovine serum (FBS), respectively. PC-BRAF and PC-HRAS were derived from $\mathrm{PCCl} 3$ rat thyroid follicular cells [57] to obtain doxycycline-inducible expression of BRAF ${ }^{\mathrm{V} 600 \mathrm{E}}$ or HRAS v12 [58, 59]. Cells were grown in Coon's modified Ham's F-12 medium supplemented with a sixhormone mixture ( $1 \mathrm{nM}$ TSH, $10 \mu \mathrm{g} / \mathrm{ml}$ insulin, $10 \mathrm{ng} / \mathrm{ml}$ somatostatin, $5 \mu \mathrm{g} / \mathrm{ml}$ transferrin, $10 \mathrm{nM}$ hydrocortisone, and $10 \mathrm{ng} / \mathrm{ml}$ glycyl-L-histidyl-L-lysine acetate) and 5\% donor calf serum (complete). To avoid the effects of TSH and IGF1 on the Wnt signaling pathway [23], PC-HRAS and PC-BRAF cells were transferred to Coon's starvation medium supplemented with $0.2 \%$ BSA plus hormones, but without TSH and insulin for $48 \mathrm{~h}$. Cells were treated with $1 \mu \mathrm{g} / \mathrm{mL}$ doxycycline for the indicated time periods to induce BRAF or HRAS expression.

Thyroid cancer cell lines were from the following sources: C643, Hth7, Hth83 and SW1736 were originally from Dr. N.E. Heldin (University of Uppsala, Uppsala, Sweden); BCPAP was from Dr. M. Santoro (University of Federico II, Naples, Italy); FTC133 and Nthy-Ori-3.1 were obtained from the European Collection of Cell cultures; WRO-82-1 was from Dr. G. J. F. Juillard (University of California-Los Angeles School of Medicine, Los Angeles, CA); TPC1 was provided by Dr. A.P. Dackiw (Johns Hopkins University, Baltimore, Maryland); KTC-1 was provided by Junichi Kurebayashi (Kawasaki Medical School, Japan); CAL62, FRO and 8505c were obtained from the Leibniz-Institut DSMZ-German Collection of Microorganisms and Cell Cultures and T238 was from Dr. Lucia Roque (Portuguese Cancer Institute, Lisbon, Portugal). Cell lines were authenticated every 6 months by short tandem repeat (STR) profiles using the Applied Biosystems Identifier kit in the Genomic Facility at the Instituto de Investigaciones Biomédicas (Madrid, Spain). Cell lines were grown at $37^{\circ} \mathrm{C}$ in RPMI 1640 with $10 \%$ FBS, except FTC133, which was cultured in DMEM. The following inhibitors were added to cells at the indicated concentrations: $10 \mu \mathrm{M}$ UO126 (Calbiochem), $10 \mu \mathrm{M}$ AKTi-VIII, $10 \mu \mathrm{M}$ XAV939 and $10 \mu \mathrm{M}$ bortezomib (Sigma).

\section{Luciferase reporter assay}

To measure $\beta$-catenin transcriptional activity, cells were transfected with Super8xTop- and Fop-Luc luciferase vectors, which contain 8 optimized and 8 mutated TCFbinding sites, respectively (both kind gifts of R.T. Moon) [60]. To measure ERK activity, cells were transfected with the reporter pGE51-luc and a vector encoding the transactivation domain of Elk-1 (amino acids 307 to 428) fused to the GAL4 DNA-binding domain [61]. Additionally, a pRL-CMV Renilla luciferase construct (Promega) was co-transfected to monitor transfection efficiency. HRAS ${ }^{\mathrm{V} 12}$ and $\mathrm{BRAF}^{\mathrm{V} 600 \mathrm{E}}$ expression vectors were used in transfection experiments as described [62].

Thyroid cancer cells were grown in DMEM or RPMI and transfected with JetPEI transfection reagent (Polyplus). Twenty-four hours after transfection, cells were treated with the indicated compounds for $24 \mathrm{~h}$ and harvested for luciferase measurement (Dual-Luciferase kit, Promega). PC-BRAF and PC-HRAS cells were transfected in Coon's complete medium using JetPEI or by calcium phosphate coprecipitation [63], grown for $48 \mathrm{~h}$ in starvation medium and treated with doxycycline for the indicated time periods. HeLa cells were grown in DMEM complete medium, transfected by calcium phosphate coprecipitation, and harvested $48 \mathrm{~h}$ later. One microgram of promoter construct was co-transfected with $1 \mu \mathrm{g}$ of the indicated expression vector. The amount of DNA in each transfection was kept constant by the addition of an appropriate amount of empty expression vector, pcDNA3.1. To normalize transfection efficiency, $50 \mathrm{ng}$ of pRL-CMV vector was added in all cases. Additionally, in the Top/Fop assays, Top activity was normalized with Fop activity to ensure that Top Flash values were dependent on the Lef1/Tcf-binding sites in the promoter. All transfection experiments were performed in triplicate and carried out at least three times.

\section{Western blotting}

Total proteins were lysed in a buffer containing $1 \%$ NP-40, 0.1\% SDS, 0.5\% deoxycholic acid, supplemented with a protease inhibitor cocktail (Roche). Nuclear 
and cytoplasmic proteins were extracted as described [64]. Protein concentration was measured according to the method of Bradford [65] using an assay from Bio-Rad Laboratories. Equal amounts of protein were diluted in loading buffer and heated at $95^{\circ} \mathrm{C}$ for $5 \mathrm{~min}$. Samples were separated by SDS-PAGE, transferred onto nitrocellulose membranes, blocked and incubated overnight with primary antibodies diluted in PBS $0.1 \%$ Tween 20 containing 5\% w/v nonfat dry milk. Antibody binding was revealed with horseradish peroxidase (HRP)conjugated secondary antibodies and immunoreactive proteins were visualized by enhanced chemiluminescence (Thermo Scientific). Protein expression levels were quantified using Image J software (NIH) and normalized to their loading controls. Antibodies to streptavidin-(HRP), AKT1/2, pAKT (S473), $\beta$-actin, $\beta$-catenin, cyclin D1, p27, pERK (Y204), ERK1/2 and tubulin were obtained from Santa Cruz Biotechnology. Antibodies to phospho$\beta$-catenin (S33/37/T41 and S552), CTCF and phosphGSK3 $\beta$ (S9) were from Cell Signaling Technology Antibodies to E-cadherin and GSK3 $\beta$ were from BD Biosciences.

\section{Semi-quantitative RT-PCR}

RNA was extracted using Trizol (Sigma) and equal amounts of RNA were added to a reverse-transcriptase reaction mix (m-MLV, Promega). Real time PCR was performed on an Mx3000 platform (Agilent) using the FastStart Universal Probe Master kit (ROX, Roche) and run for 40 cycles. Specificity of the reactions was determined by subsequent melting curve analysis. Stratagene analysis software was used to remove background fluorescence [66]. The number of cycles needed to reach the crossing point for each sample was used to calculate the amount of each product using the $2^{-\Delta \Delta C t}$ method. The levels of PCR product were expressed as a function of actin. The primers used are listed in Supplementary Table 1.

\section{Immunofluorescence}

Cells were seeded onto coverslips and treated as indicated. Unfixed tumors were embedded in OCT (Tissue tek). Frozen tissue was sectioned (10 $\mu \mathrm{m}$, Leica cryostat) and mounted on SuperFrost Plus slides (Fisher). Cells and frozen sections were fixed with $4 \%$ paraformaldehyde in PBS pH 7.4 for 10 min, rinsed with PBS, permeabilized with $0.5 \%$ Triton X-100, and blocked with $1 \%$ BSA. After over-night incubation with primary $\beta$-catenin $(\mathrm{C}-18)$ or phospho-Ser552 $\beta$-catenin antibodies [67] (provided by Dr. Linheng Li), samples were rinsed with PBS and incubated with Alexa 488 or Texas Red 546 secondary antibodies for one hour, mounted with ProLong ${ }^{\circledR}$ Gold antifade reagent with DAPI (Invitrogen) and observed under a confocal microscope with a $63 \times$ magnification objective (Leica).

\section{Lentivirus production and cell infection}

Stable thyroid cancer cell lines were generated using lentiviral expression vectors. For the generation of $\beta$-catenin-silenced cells ( $\operatorname{sh} \beta$-cat) the vector encoded an shRNA against human $\beta$ catenin (pLKO.1-shbcat; Open Biosystem clone TRCN0000003845). Control cells (shScramble) were infected with virus containing a non-coding control DNA (pGIPZ-shscramble, Open Biosystem). Cells expressing a dominant negative form of TCF (dnTCF4) were generated using the vector EdTP (vector was from Addgene and is described in [36]). VSV-G pseudotyped lentivirus production was performed as previously described [23]. Forty-eight hours after infection, puromycin-resistant cells were selected with $1 \mu \mathrm{g} / \mathrm{ml}$ of puromycin (Sigma).

\section{Cell proliferation and BrdU incorporation assay}

To determine cell proliferation cells were plated at 2 $\times 10^{5}$ cell per well in 24-well plates. Cells were fixed at the indicated times with $1 \%$ glutaraldehyde and stained with crystal violet. After extensive washing, crystal violet was resolubilized in $1 \%$ acetic acid and quantified at $595 \mathrm{~nm}$ as an indirect measure of cell number. DNA synthesis was determined using the Cell Proliferation ELISA BrdU Assay (Roche Molecular Biochemicals). Briefly, cells were seeded in 96 -well plates $\left(5 \times 10^{3}\right.$ cells/well $)$. Twenty-four hours later, cells were pulse labeled for $2 \mathrm{~h}$ with $10 \mu \mathrm{M}$ $\mathrm{BrdU}$, and measurements were carried on an ELISA reader at $450 \mathrm{~nm}$. Experiments were performed three times in triplicate.

\section{Senescence assay (SA- $\beta$-gal staining)}

Thyroid cells were infected and selected and plated on 12 -well plates $\left(7 \times 10^{5}\right.$ cells/well). Twenty-four hours later, cells were fixed and assayed for SA- $\beta$-gal activity using the Senescence Detection kit (BioVision). To obtain the percentage of SA- $\beta$-gal positive cells, four images of each condition were captured using $10 \times$ magnification and quantified. Experiments were repeated at least three times.

\section{Invasion assay}

Invasion was measured in Transwell cell culture chambers using BD BioCoat Matrigel Invasion Chambers (BD Bioscience). Infected FTC133 cells $\left(2.5 \times 10^{4}\right)$ were placed on the upper chamber in DMEM plus $0.2 \%$ FBS. The lower chamber contained DMEM supplemented with $15 \% \mathrm{FBS}$. Cells were allowed to invade for $24 \mathrm{~h}$ at $37^{\circ} \mathrm{C}$ and $5 \% \mathrm{CO}_{2}$. Nonmigrated cells on the upper chamber were removed with a cotton swab; filters were fixed in $4 \%$ paraformaldehyde and stained using the Diff-Quik staining kit (BD Biosciences). The total number of cells migrated to the lower surface was counted. The experiments were repeated three times. 


\section{Xenograft studies in mice}

Protocols for animal handling were approved by the Institutional Animal Care Committee, following the rules of the European Union and the National Institutes of Health. Animals were housed in temperature-controlled rooms $\left(22 \pm 2^{\circ} \mathrm{C}\right)$ with 12-h light/dark cycles (lights on at $07: 00 \mathrm{~h}$ ) and had free access to food and water. For xenograft studies $9 \times 10^{6} \mathrm{FTC133}$ shScramble or $\operatorname{sh} \beta$-cat cells were subcutaneously injected into two-month-old female NOD-SCID mice. Tumors were measured every 4 days and the tumor volume was calculated as $\pi^{*} 1 * \mathrm{w} / 6$, where $\mathrm{l}=$ length in $\mathrm{mm}$ and $\mathrm{w}=$ width in $\mathrm{mm}$.

\section{Statistical Analysis}

Results are presented as mean fold induction \pm SEM from at least three independent biological experiments. Student's two-tailed $t$-test was used to assess differences between measurements. Differences were considered statistically significant if $p<0.05$.

\section{ACKNOWLEDGMENTS}

The authors thank Dr. Linheng Li (Department of Pathology and Laboratory Medicine, Kansas University Medical Center, Kansas City, Kansas) for providing the phospho- Ser552 $\beta$-catenin antibody.

\section{CONFLICTS OF INTEREST}

The authors declare no potential conflicts of interest.

\section{FUNDING}

This work was supported by grants SAF201344709-R from the Ministerio de Economía y Competitividad of Spain and Fondo Europeo de Desarrollo Regional (FEDER), RD12/0036/0030 from Instituto de Salud Carlos III (ISCIII), S2011/BMD-2328 from Comunidad de Madrid, and GCB14142311CRES from Fundación Española contra el Cancer (AECC).

AS-P was supported by predoctoral FPU fellowship from the Ministerio de Economía y Competitividad and MA-Z has a research contract of AECC (GCB14142311CRES) We are also grateful to Dr. Kenneth McCreath for helpful comments on the manuscript.

\section{REFERENCES}

1. Nikiforov YE, Nikiforova MN. Molecular genetics and diagnosis of thyroid cancer. Nat Rev Endocrinol. 2011; 7:569-580.

2. Riesco-Eizaguirre G, Santisteban P. Molecular biology of thyroid cancer initiation. Clin Transl Oncol. 2007; 9:686-693.
3. Xing M. Molecular pathogenesis and mechanisms of thyroid cancer. Nat Rev Cancer. 2013; 13:184-199.

4. Kimura ET, Nikiforova MN, Zhu Z, Knauf JA, Nikiforov YE, Fagin JA. High prevalence of BRAF mutations in thyroid cancer: genetic evidence for constitutive activation of the RET/PTC-RAS-BRAF signaling pathway in papillary thyroid carcinoma. Cancer Res. 2003; 63:1454-1457.

5. Soares P, Trovisco V, Rocha AS, Lima J, Castro P, Preto A, Maximo V, Botelho T, Seruca R, SobrinhoSimoes M. BRAF mutations and RET/PTC rearrangements are alternative events in the etiopathogenesis of PTC. Oncogene. 2003; 22:4578-4580.

6. Frattini M, Ferrario C, Bressan P, Balestra D, De Cecco L, Mondellini P, Bongarzone I, Collini P, Gariboldi M, Pilotti S, Pierotti MA, Greco A. Alternative mutations of BRAF, RET, NTRK1 are associated with similar but distinct gene expression patterns in papillary thyroid cancer. Oncogene. 2004; 23:7436-7440.

7. Adeniran AJ, Zhu Z, Gandhi M, Steward DL, Fidler JP, Giordano TJ, Biddinger PW, Nikiforov YE. Correlation between genetic alterations and microscopic features, clinical manifestations, and prognostic characteristics of thyroid papillary carcinomas. Am J Surg Pathol. 2006; 30:216-222.

8. Cohen Y, Xing M, Mambo E, Guo Z, Wu G, Trink B, Beller U, Westra WH, Ladenson PW, Sidransky D. BRAF mutation in papillary thyroid carcinoma. J Natl Cancer Inst. 2003; 95:625-627.

9. Hou P, Liu D, Shan Y, Hu S, Studeman K, Condouris S, Wang Y, Trink A, El-Naggar AK, Tallini G, Vasko V, Xing M. Genetic alterations and their relationship in the phosphatidylinositol 3-kinase/Akt pathway in thyroid cancer. Clin Cancer Res. 2007; 13:1161-1170.

10. Liu D, Yang C, Bojdani E, Murugan AK, Xing $M$. Identification of RASAL1 as a major tumor suppressor gene in thyroid cancer. J Natl Cancer Inst. 2013; 105:1617-1627.

11. Ngeow J, Eng C. RASAL1 in thyroid cancer: wisdom from an old foe. J Natl Cancer Inst. 2013; 105:1597-1599.

12. Sastre-Perona A, Santisteban P. Role of the wnt pathway in thyroid cancer. Front Endocrinol (Lausanne). 2012; 3:31.

13. Garcia-Rostan G, Tallini G, Herrero A, D’Aquila TG, Carcangiu ML, Rimm DL. Frequent mutation and nuclear localization of beta-catenin in anaplastic thyroid carcinoma. Cancer Res. 1999; 59:1811-1815.

14. Garcia-Rostan G, Camp RL, Herrero A, Carcangiu ML, Rimm DL, Tallini G. Beta-catenin dysregulation in thyroid neoplasms: down-regulation, aberrant nuclear expression, and CTNNB1 exon 3 mutations are markers for aggressive tumor phenotypes and poor prognosis. Am J Pathol. 2001; 158:987-996.

15. Ishigaki $K$, Namba $H$, Nakashima $M$, Nakayama $T$, Mitsutake N, Hayashi T, Maeda S, Ichinose M, Kanematsu T, Yamashita S. Aberrant localization of betacatenin correlates with overexpression of its target gene in 
human papillary thyroid cancer. J Clin Endocrinol Metab. 2002; 87:3433-3440.

16. Lazzereschi D, Sambuco L, Carnovale Scalzo C, Ranieri A, Mincione G, Nardi F, Colletta G. Cyclin D1 and Cyclin E expression in malignant thyroid cells and in human thyroid carcinomas. Int J Cancer. 1998; 76:806-811.

17. Meirmanov S, Nakashima M, Kondo H, Matsufuji R, Takamura N, Ishigaki K, Ito M, Prouglo Y, Yamashita S, Sekine I. Correlation of cytoplasmic beta-catenin and cyclin D1 overexpression during thyroid carcinogenesis around Semipalatinsk nuclear test site. Thyroid. 2003; 13:537-545.

18. Rezk S, Brynes RK, Nelson V, Thein M, Patwardhan N, Fischer A, Khan A. beta-Catenin expression in thyroid follicular lesions: potential role in nuclear envelope changes in papillary carcinomas. Endocr Pathol. 2004; 15:329-337.

19. Zhang J, Gill AJ, Issacs JD, Atmore B, Johns A, Delbridge LW, Lai R, McMullen TP. The Wnt/beta-catenin pathway drives increased cyclin D1 levels in lymph node metastasis in papillary thyroid cancer. Hum Pathol. 2012; 43:1044-50. doi: 10.1016/j.humpath.2011.08.013.

20. Cross DA, Alessi DR, Cohen P, Andjelkovich M, Hemmings BA. Inhibition of glycogen synthase kinase-3 by insulin mediated by protein kinase B. Nature. 1995; 378:785-789.

21. Fang D, Hawke D, Zheng Y, Xia Y, Meisenhelder J, Nika H, Mills GB, Kobayashi R, Hunter T, Lu Z. Phosphorylation of beta-catenin by AKT promotes beta-catenin transcriptional activity. J Biol Chem. 2007; 282:11221-11229.

22. Lee G, Goretsky T, Managlia E, Dirisina R, Singh AP, Brown JB, May R, Yang GY, Ragheb JW, Evers BM, Weber CR, Turner JR, He XC, et al. Phosphoinositide 3-kinase signaling mediates beta-catenin activation in intestinal epithelial stem and progenitor cells in colitis. Gastroenterology. 2010; 139:869-881, 881 e861-869.

23. Sastre-Perona A, Santisteban P. Wnt-independent role of beta-catenin in thyroid cell proliferation and differentiation. Mol Endocrinol. 2014; 28:681-695.

24. Ding Q, Xia W, Liu JC, Yang JY, Lee DF, Xia J, Bartholomeusz G, Li Y, Pan Y, Li Z, Bargou RC, Qin J, Lai CC, et al. Erk associates with and primes GSK-3beta for its inactivation resulting in upregulation of beta-catenin. Mol Cell. 2005; 19:159-170.

25. Castellone MD, De Falco V, Rao DM, Bellelli R, Muthu M, Basolo F, Fusco A, Gutkind JS, Santoro M. The beta-catenin axis integrates multiple signals downstream from RET/ papillary thyroid carcinoma leading to cell proliferation. Cancer Res. 2009; 69:1867-1876.

26. Cassinelli G, Favini E, Degl'Innocenti D, Salvi A, De Petro G, Pierotti MA, Zunino F, Borrello MG, Lanzi C. RET/PTC1driven neoplastic transformation and proinvasive phenotype of human thyrocytes involve Met induction and beta-catenin nuclear translocation. Neoplasia. 2009; 11:10-21.

27. Tartari CJ, Donadoni C, Manieri E, Mologni L, Mina PD, Villa A, Gambacorti-Passerini C. Dissection of the RET/ beta-catenin interaction in the TPC1 thyroid cancer cell line. Am J Cancer Res. 2011; 1:716-725.
28. Cancer Genome Atlas Research N. Integrated genomic characterization of papillary thyroid carcinoma. Cell. 2014; 159:676-690.

29. Hsi LC, Angerman-Stewart J, Eling TE. Introduction of full-length APC modulates cyclooxygenase-2 expression in HT-29 human colorectal carcinoma cells at the translational level. Carcinogenesis. 1999; 20:2045-2049.

30. Lemoine NR, Mayall ES, Jones T, Sheer D, McDermid S, Kendall-Taylor P, Wynford-Thomas D. Characterisation of human thyroid epithelial cells immortalised in vitro by simian virus 40 DNA transfection. Br J Cancer. 1989; 60:897-903.

31. Korinek V, Barker N, Morin PJ, van Wichen D, de Weger R, Kinzler KW, Vogelstein B, Clevers H. Constitutive transcriptional activation by a beta-catenin-Tcf complex in APC-/- colon carcinoma. Science. 1997; 275:1784-1787.

32. Tian Q, Feetham MC, Tao WA, He XC, Li L, Aebersold R, Hood L. Proteomic analysis identifies that 14-3-3zeta interacts with beta-catenin and facilitates its activation by Akt. Proc Natl Acad Sci U S A. 2004; 101:15370-15375.

33. De Vita G, Bauer L, da Costa VM, De Felice M, Baratta MG, De Menna M, Di Lauro R. Dose-dependent inhibition of thyroid differentiation by RAS oncogenes. Mol Endocrinol. 2005; 19:76-89.

34. Baratta MG, Porreca I, Di Lauro R. Oncogenic ras blocks the cAMP pathway and dedifferentiates thyroid cells via an impairment of pax8 transcriptional activity. Mol Endocrinol. 2009; 23:838-848.

35. Huang SM, Mishina YM, Liu S, Cheung A, Stegmeier F, Michaud GA, Charlat O, Wiellette E, Zhang Y, Wiessner S, Hild M, Shi X, Wilson CJ, et al. Tankyrase inhibition stabilizes axin and antagonizes Wnt signalling. Nature. 2009; 461:614-620.

36. Fuerer C, Nusse R. Lentiviral vectors to probe and manipulate the Wnt signaling pathway. PLoS One. 2010; 5:e9370.

37. Li DM, Sun H. PTEN/MMAC1/TEP1 suppresses the tumorigenicity and induces G1 cell cycle arrest in human glioblastoma cells. Proc Natl Acad Sci U S A. 1998; 95:15406-15411.

38. Fukami-Kobayashi J, Mitsui Y. The regulation of cyclin D1 expression in senescent human fibroblasts. Exp Cell Res. $1998 ; 241: 435-444$.

39. Burton DG, Sheerin AN, Ostler EL, Smith K, Giles PJ, Lowe J, Rhys-Williams W, Kipling DG, Faragher RG. Cyclin D1 overexpression permits the reproducible detection of senescent human vascular smooth muscle cells. Ann N Y Acad Sci. 2007; 1119:20-31.

40. Peinado H, Olmeda D, Cano A. Snail, Zeb and bHLH factors in tumour progression: an alliance against the epithelial phenotype? Nat Rev Cancer. 2007; 7:415-428.

41. Knauf JA, Sartor MA, Medvedovic M, Lundsmith E, Ryder M, Salzano M, Nikiforov YE, Giordano TJ, Ghossein RA, Fagin JA. Progression of BRAF-induced thyroid cancer is associated with epithelial-mesenchymal 
transition requiring concomitant MAP kinase and TGFbeta signaling. Oncogene. 2011; 30:3153-3162.

42. Sakai D, Tanaka Y, Endo Y, Osumi N, Okamoto H, Wakamatsu Y. Regulation of Slug transcription in embryonic ectoderm by beta-catenin-Lef/Tcf and BMPSmad signaling. Dev Growth Differ. 2005; 47:471-482.

43. Wels C, Joshi S, Koefinger P, Bergler H, Schaider H. Transcriptional activation of ZEB1 by Slug leads to cooperative regulation of the epithelial-mesenchymal transition-like phenotype in melanoma. J Invest Dermatol. 2011; 131:1877-1885.

44. Damsky WE, Curley DP, Santhanakrishnan M, Rosenbaum LE, Platt JT, Gould Rothberg BE, Taketo MM, Dankort D, Rimm DL, McMahon M, Bosenberg M. betacatenin signaling controls metastasis in Braf-activated Ptendeficient melanomas. Cancer Cell. 2011; 20:741-754.

45. Lodyga M, De Falco V, Bai XH, Kapus A, Melillo RM, Santoro M, Liu M. XB130, a tissue-specific adaptor protein that couples the RET/PTC oncogenic kinase to PI 3-kinase pathway. Oncogene. 2009; 28:937-949.

46. Xing M. Genetic alterations in the phosphatidylinositol-3 kinase/Akt pathway in thyroid cancer. Thyroid. 2010; 20:697-706.

47. Ricarte-Filho JC, Ryder M, Chitale DA, Rivera M, Heguy A, Ladanyi M, Janakiraman M, Solit D, Knauf JA, Tuttle RM, Ghossein RA, Fagin JA. Mutational profile of advanced primary and metastatic radioactive iodinerefractory thyroid cancers reveals distinct pathogenetic roles for BRAF, PIK3CA, and AKT1. Cancer Res. 2009; 69:4885-4893.

48. Liu Z, Hou P, Ji M, Guan H, Studeman K, Jensen K, Vasko V, El-Naggar AK, Xing M. Highly prevalent genetic alterations in receptor tyrosine kinases and phosphatidylinositol 3-kinase/akt and mitogen-activated protein kinase pathways in anaplastic and follicular thyroid cancers. J Clin Endocrinol Metab. 2008; 93:3106-3116.

49. Tetsu O, McCormick F. Beta-catenin regulates expression of cyclin D1 in colon carcinoma cells. Nature. 1999; 398:422-426.

50. Essers MA, de Vries-Smits LM, Barker N, Polderman PE, Burgering BM, Korswagen HC. Functional interaction between beta-catenin and FOXO in oxidative stress signaling. Science. 2005; 308:1181-1184.

51. Botrugno OA, Fayard E, Annicotte JS, Haby C, Brennan T, Wendling O, Tanaka T, Kodama T, Thomas W, Auwerx J, Schoonjans K. Synergy between LRH-1 and beta-catenin induces G1 cyclin-mediated cell proliferation. Mol Cell. 2004; 15:499-509.

52. Arozarena I, Calvo F, Crespo P. Ras, an actor on many stages: posttranslational modifications, localization, and site-specified events. Genes Cancer. 2011; 2:182-194. doi: 10.1177/1947601911409213.

53. Piedra J, Martinez D, Castano J, Miravet S, Dunach M and de Herreros AG. Regulation of beta-catenin structure and activity by tyrosine phosphorylation. J Biol Chem. 2001; 276:20436-20443.

54. van Veelen $\mathrm{W}$, Le NH, Helvensteijn W, Blonden L, Theeuwes M, Bakker ER, Franken PF, van Gurp L, Meijlink F, van der Valk MA, Kuipers EJ, Fodde R, Smits R. beta-catenin tyrosine 654 phosphorylation increases Wnt signalling and intestinal tumorigenesis. Gut. 2011; 60:1204-1212.

55. Spitzweg C, Bible KC, Hofbauer LC, Morris JC. Advanced radioiodine-refractory differentiated thyroid cancer: the sodium iodide symporter and other emerging therapeutic targets. Lancet Diabetes Endocrinol. 2014; 2:830-842.

56. Gujral TS, van Veelen W, Richardson DS, Myers SM, Meens JA, Acton DS, Dunach M, Elliott BE, Hoppener JW, Mulligan LM. A novel RET kinase-beta-catenin signaling pathway contributes to tumorigenesis in thyroid carcinoma. Cancer Res. 2008; 68:1338-1346.

57. Fusco A, Berlingieri MT, Di Fiore PP, Portella G, Grieco $\mathrm{M}$, Vecchio G. One- and two-step transformations of rat thyroid epithelial cells by retroviral oncogenes. Mol Cell Biol. 1987; 7:3365-3370.

58. Shirokawa JM, Elisei R, Knauf JA, Hara T, Wang J, Saavedra HI, Fagin JA. Conditional apoptosis induced by oncogenic ras in thyroid cells. Mol Endocrinol. 2000; 14:1725-1738.

59. Mitsutake N, Knauf JA, Mitsutake S, Mesa C Jr, Zhang L, Fagin JA. Conditional BRAFV600E expression induces DNA synthesis, apoptosis, dedifferentiation, and chromosomal instability in thyroid PCCL3 cells. Cancer Res. 2005; 65:2465-2473.

60. Veeman MT, Axelrod JD, Moon RT. A second canon. Functions and mechanisms of beta-catenin-independent Wnt signaling. Dev Cell. 2003; 5:367-377.

61. Sanz-Moreno V, Casar B, Crespo P. p38alpha isoform Mxi2 binds to extracellular signal-regulated kinase 1 and 2 mitogen-activated protein kinase and regulates its nuclear activity by sustaining its phosphorylation levels. Mol Cell Biol. 2003; 23:3079-3090.

62. Marais R, Marshall CJ. Control of the ERK MAP kinase cascade by Ras and Raf. Cancer Surv. 1996; 27:101-125.

63. Chen CA, Okayama H. Calcium phosphate-mediated gene transfer: a highly efficient transfection system for stably transforming cells with plasmid DNA. Biotechniques. 1988; 6:632-638.

64. Perona R, Montaner S, Saniger L, Sanchez-Perez I, Bravo R, Lacal JC. Activation of the nuclear factor-kappaB by Rho, CDC42, and Rac-1 proteins. Genes Dev. 1997; 11:463-475.

65. Bradford MM. A rapid and sensitive method for the quantitation of microgram quantities of protein utilizing the principle of protein-dye binding. Anal Biochem. 1976; $72: 248-254$. 
66. Nellore A, Paziana K, Ma C, Tsygankova OM, Wang Y, Puttaswamy K, Iqbal AU, Franks SR, Lv Y, Troxel AB, Feldman MD, Meinkoth JL, Brose MS. Loss of Rap1GAP in papillary thyroid cancer. J Clin Endocrinol Metab. 2009; 94:1026-1032.
67. He XC, Yin T, Grindley JC, Tian Q, Sato T, Tao WA, Dirisina R, Porter-Westpfahl KS, Hembree M, Johnson T, Wiedemann LM, Barrett TA, Hood L, et al. PTEN-deficient intestinal stem cells initiate intestinal polyposis. Nat Genet. 2007; 39:189-198. 